\title{
Cadmium - a metallohormone?
}

\author{
Celia Byrne $^{1}$, Shailaja D. Divekar ${ }^{2}$, Geoffrey B. Storchan $^{2}$, Daniela A. Parodi ${ }^{2}$, and Mary Beth \\ Martin $1,2,3$ \\ ${ }^{1}$ Department of Oncology, Lombardi Comprehensive Cancer Center, Georgetown University, \\ Washington, DC \\ 2Department of Biochemistry and Molecular \& Cellular Biology, Lombardi Comprehensive Cancer \\ Center, Georgetown University, Washington, DC
}

\begin{abstract}
Cadmium is a heavy metal that is often referred to as the metal of the $20^{\text {th }}$ Century. It is widely used in industry principally in galvanizing and electroplating, in batteries, in electrical conductors, in the manufacture of alloys, pigments, and plastics, and in the stabilization of phosphate fertilizers. As a byproduct of smelters, cadmium is a prevalent environmental contaminant. In the general population, exposure to cadmium occurs primarily through dietary sources, cigarette smoking, and, to a lesser degree, drinking water. Although the metal has no known physiological function, there is evidence to suggest that the cadmium is a potent metallohormone. This review summarizes the increasing evidence that cadmium mimics the function of steroid hormones, addresses our current understanding of the mechanism by which cadmium functions as a hormone, and discusses its potential role in development of the hormone dependent cancers.
\end{abstract}

\section{ENVIRONMENTAL ESTROGENS}

Estrogens are a family of steroidal hormones that are synthesized in a variety of tissues but during a women's reproductive years are produced primarily in the ovaries. The most recognized functions of estrogens are to promote the growth and differentiation of secondary sex tissues and organs in the female reproductive system. In addition to the reproductive system, estrogens play an important role in the function of the brain, in the maintenance of bone, and in the accumulation of adipose tissue. The central role of estrogens in the reproductive system has lead to the suggestion that environmental exposures that mimic the biological effects of estradiol are an underlying cause for the reproductive disorders of wild animals and the high incidence of hormone related diseases and cancers in Western populations. In the United States, it is currently estimated that the lifetime risk of developing breast cancer is one in eight for women. Every year, approximately 200,000 new cases of breast cancer are diagnosed and approximately 40,000 women die from the disease.

Over the past several decades, the global incidence rate of breast cancer has increased continuously (Richie et al., 2003; Althuis et al., 2005), yet the underlying causes of the increase are largely unknown. Screening practices, access to mammography, and the use of exogenous estrogens and progestins contributed to the high incidence rates during the 1980s, but do not explain the increase in incidence rates before the 1980s or the increase in countries with low rates of screening and use of hormones (Ursin et al., 1994). It has been suggested that the continuous increase in incidence is due to a combination of an increase in the prevalence of

\footnotetext{
${ }^{3}$ To whom correspondences should be addressed: Mary Beth Martin, Ph.D., Georgetown University, Lombardi Comprehensive Cancer Center, Research Building, 3970 Reservoir Road NW, Washington, DC 20007. Phone: 202-687-3768; FAX 202-687-7505; E-mail: martinmb@georgetown.edu.
} 
exposures to known risk factors and to new unidentified risk factors (Feigelson et al., 2004;Althuis et al., 2005). Family history is a risk factor for developing breast cancer (Miki et al., 1994), but only 5-10\% of breast cancers are associated with the highly penetrant BRCA1 and BRCA2 genes (Miki et al., 1994). Endocrine status, on the other hand, is a prominent risk factor for developing the disease. Early age at menarche (Kampert et al., 1988;Pike et al., 1981), late age at menopause (Lippman, 1985;Henderson et al., 1985), and later age at first full-term pregnancy (MacMahon et al., 1973) increase the risk of developing breast cancer. Endogenous and exogenous exposure to estrogens and progestins after menopause increase the risk of postmenopausal breast cancer (Hoover et al., 1976;Hankinson et al., 1998; Toniolo et al., 1995). A history of benign breast disease also increases the risk of developing breast cancer. However, these well established risk factors, i.e., family history, reproductive and menstrual history, and history of benign breast disease, are estimated to account for only about $40 \%$ of breast cancer cases (Madigan et al., 1995). Childhood exposure to ionizing radiation (Boice, Jr. et al., 1999;Land, 1995;Tokunaga et al., 1987), adult alcohol consumption (Dorgan et al., 2001), and obesity (Yong et al., 1996; Feigelson et al., 2004) also increase the risk of the disease. However, these highly prevalent, but modest, risk factors are unlikely to account for the remaining cases of breast cancer (Feigelson et al., 2004;Feuer et al., 1993;Althuis et al., 2005) supporting the hypothesis that there are still unidentified risk factors for developing the disease.

The prominence of estrogens in the etiology of breast cancer suggests that environmental exposures that mimic the effects of estrogens may be potential risk factors for the disease. Although a number of chemicals in the environment demonstrate estrogen like activity (reviewed in Colborn et al., 1993), the influence of these environmental estrogens in breast cancer etiology is not clear. Phytoestrogens are naturally occurring plant compounds that exhibit mixed weak estrogen agonist and antagonist activity. Phytoestrogens are classified into several groups including the isoflavones (e.g., genistein, daidzein, and biochanin A), the lignans (e.g., enterolactone and enterodiol), the coumestans (e.g., coumestrol), and the stilbenes (e.g., resveratrol). Early ecological and epidemiological studies showing that Asian populations that consume diets rich in phytoestrogens had a lower incidence of breast cancer raised the possibility that phytoestrogens may be effective chemopreventive agents for breast cancer. However, most epidemiological studies did not show a protective effect (reviewed in Peeters et al., 2003) that, in part, may be due to the weak, differential affinity of phytoestrogens for the two isoforms of the estrogen receptor (ER $\alpha$ and ER $\beta$ ).

While phytoestrogens are thought to be protective for breast cancer, xenoestrogens are thought to increase the risk of breast cancer. Xenoestrogens are synthetic chemical contaminants in the environment that represent a structurally diverse group of hydrocarbons. Many xenoestrogens contain one or two aromatic rings and some xenoestrogens are chlorinated giving them a negative charge. Bisphenol A is a xenobiotic that was originally synthesized for pharmaceutical use as a synthetic estrogen but was later used as a crosslinking reagent in the production of plastic. However, most xenoestrogens were not designed to activate the estrogen receptors. Organochlorides, such as dicholorodiphenyltrichloroethane (DDT) and kepone, were designed for use as pesticides while alkylphenols were used in the manufacture of plastics and detergents and as antioxidants. Polychlorinated biphenyls (PCBs) are also prominent environmental contaminants that mimic the effects of estrogens (Colborn et al., 1993). Because of their persistence in the environment and the availability of analytical protocols, most exposure studies have focused on PCBs and the metabolite of DDT, p,p'-dichlorodiphenyl dichloroethylene (DDE), and the risk of developing breast cancer. However, these studies did not show a clear correlation between PCBs and/or DDE and the disease (reviewed in Safe, 2004). It has been suggested that the lack of correlation is due, in part, to low affinity of these chemicals for the estrogen receptor (Safe, 1995). In addition to phytoestrogens and xenoestrogens, a new class of environmental estrogens referred to as metalloestrogens has been 
identified. Metalloestrogens include the heavy metals and metalloids cadmium, aluminum, antimony, arsenite, barium, cobalt, copper, chromium, lead, mercury, nickel, nitrite, selenite, tin, uranium and vanadate (Johnson et al., 2003;Garcia-Morales et al., 1994;Stoica et al., 2000a;Stoica et al., 2000b;Stoica et al., 2000c;Martin et al., 2003;Darbre, 2005;Choe et al., 2003;Raymond-Whish et al., 2007; Veselik et al., 2008).

\section{ESTROGENIC EFFECTS OF CADMIUM}

The MCF-7 cells are a hormone dependent human breast cancer cells that require estrogens for growth (Brooks et al., 1973). Similar to estradiol, cadmium induces proliferation (GarciaMorales et al., 1994;Brama et al., 2007;Martinez-Campa et al., 2006), increases the transcription and expression of estrogen regulated genes such as the progesterone receptor (Garcia-Morales et al., 1994), and activates ER $\alpha$ in transient transfection assays (GarciaMorales et al., 1994;Stoica et al., 2000a;Wilson et al., 2004;Martinez-Campa et al., 2006). The effects of cadmium are blocked by an antiestrogen suggesting that the effects of the metal are mediated by the ER $\alpha$ genomic pathway. Additional evidence shows that cadmium also activates the nongenomic ER $\alpha$ pathways through ERK1/2 and Akt (Brama et al., 2007; Liu et al., 2008). More importantly, at a dose similar to the World Health Organization Provisional Tolerable Weekly Intake, cadmium mimics the in vivo effects of estrogen in target organs in animal studies (Johnson et al., 2003). Similar to estrogens, exposure of ovariectomized animals to a low dose of cadmium (5 ug per kg body weight) results in the induction of estrogen target genes and an increase in uterine wet weight that are blocked by an antiestrogen. Histological examination of the uterus reveals that the increase in weight is accompanied by a proliferative response of the endometrium. In the mammary gland, exposure to cadmium also induces estrogen target genes and promotes the growth and differentiation that are blocked by an antiestrogen. There is an increase in side branching of the mammary ducts and in the number of alveolar buds. Immunocytochemical analysis demonstrates production of casein and whey acidic protein in the ducts suggesting that the metal induces a secretory differentiation of the mammary gland (Johnson et al., 2003). Furthermore, in utero exposure to cadmium mimics in utero exposure to estradiol. Female offspring, exposed while in utero to the metal, have an accelerated onset of puberty and altered mammary gland development. Taken together, these experimental data provide strong evidence that exposure to environmentally relevant doses of cadmium may increase the risk of breast cancer due to its ability to activate ER $\alpha$.

In support of a role for cadmium in breast cancer, exposure to the metal has been linked to an increased risk of the disease in a hypothesis-generating case-control study that examined over 33,000 death certificates attributed to breast cancer and over 117,000 non-cancer deaths between 1984-1989 that were coded for occupation and industry (Cantor et al., 1994). The study found that cadmium was associated with an approximate 8 to $20 \%$ increase in breast cancer risk among white women and 50 to $130 \%$ increase in risk among African-American women. As acknowledged by the authors, the method of determining exposure (e.g., a single occupation listed on the death certificate, based on information from a proxy) may have subjected the study to substantial non-differential misclassification which can markedly attenuate the observed odds ratios leading to an underestimation of risk. Furthermore, there was no information on other breast cancer risk factors that could have further distorted the results. A second epidemiological study in a retrospective cohort of working Swedish women also suggests a link between occupational exposure to cadmium and an increased risk of breast cancer (Ursin et al., 1994). In this study, women employed as metal platers and coaters had the highest standardized incidence ratio. Metal plating and coating exposes workers to cadmium, hexavalent chromium, and organic solvents. A recent population based case-control study, which measured cadmium in urine, found that $25 \%$ of the women with the highest level of cadmium have more than two-fold increased risk of breast cancer (odds ratio [OR]: 2.29; $95 \%$ confidence interval [CI]; 1.3-4.2) than the $25 \%$ of women with the lowest level of 
cadmium and estimates that approximately $36 \%$ of breast cancer may be attributed to exposure to the metal (McElroy et al., 2006). Since the latter study was conducted in breast cancer patients treated for the disease, the study did not establish whether cadmium was associated with the risk of developing breast cancer or was a consequence of the disease and/or treatment. Although these studies do not demonstrate a clear cause and effect relationship between cadmium and breast cancer, the studies support the hypothesis that exposure to cadmium increases the risk of the disease. Endometrial cancer is another estrogen related cancer. A more recent population-based prospective cohort study showed that long term dietary intake of cadmium is associated with a 2.9 -fold increased risk in postmenopausal women (95\% CI; 1.05-7.79) (Akesson et al., 2008) providing additional support of the hypothesis that exposure to cadmium increases the risk of hormone dependent cancer. Although the epidemiological studies suggest a link between cadmium and breast and endometrial cancers, more experimental and epidemiological studies are required to establish a cause and effect association between the metal and hormone dependent cancers and to verify the mechanism of action.

\section{ESTROGEN RECEPTOR STRUCTURE AND FUNCTION}

The actions of estrogens in the breast are mediated by two isoforms of the estrogen receptor, alpha and beta. Although the precise role of the ER isoforms in mediating the effects of estradiol in the breast is not well defined, it is thought that ER $\alpha$ mediates the mitogenic actions of estradiol while ER $\beta$ mediates an antimitogenic effect (reviewed in Pettersson et al., 2001). In support of this hypothesis, the mammary gland from ER $\beta$ knockout mice are indistinguishable from wild type animals, while the glands from ER $\alpha$ knockout mice are underdeveloped providing evidence that ER $\alpha$ mediates the mitogenic effects. The uteri of ER $\beta$ knockout mice also demonstrate an increase in proliferation and a hypersensitivity to estradiol providing additional support for the mitogenic actions of ER $\alpha$ and the antimitogenic actions of ER $\beta$. In transcription assays, ER $\beta$ is less active than ER $\alpha$ and in cotransfection assays, ER $\beta$ inhibits the activity of ER $\alpha$ (Pettersson et al., 2000;Cowley et al., 1997) supporting the opposing effects of $E R \alpha$ and $E R \beta$.

Estrogen receptor-alpha is divided into domains, termed A through $\mathrm{F}$ (figure 1A) (Kumar $e t$ al., 1987). Region $\mathrm{A} / \mathrm{B}$ is the variable $\mathrm{N}$-terminal region of the receptor which has a modulatory effect on the transactivation of transcription through a domain referred to as activation function 1 (AF-1) (Kumar et al., 1987). The central domain, region C, is a short well conserved cysteine rich region which corresponds to the DNA binding domain (Krust et al., 1986). Two DNA binding fingers are formed when cysteines tetrahedrically coordinate with a zinc ion; the intervening amino acids form fingers which interact specifically with DNA. The N-terminal zinc finger contacts the major groove of one half of the palindrome of the estrogen response element in the DNA of target genes, whereas, the C-terminal zinc finger contacts the sugar phosphate backbone of the flanking sequences. In addition to a role in DNA binding, the Nterminal zinc finger appears to play a role in transactivation. There is also a weak constitutive dimerization domain in the DNA domain. The most structurally and functionally complex region of the receptor is the $\mathrm{C}$-terminal domain which corresponds to regions $\mathrm{D}, \mathrm{E}$, and $\mathrm{F}$. Region $\mathrm{E}$ is the ligand binding domain. In addition to binding hormone, the ligand binding domain functions to inhibit the DNA binding domain of the receptor. In the absence of hormone, ER $\alpha$ is sequestered in an inactive, repressed complex with molecular chaperones such as heat shock proteins. Hormone binding induces a conformation change in the ligand binding domain that releases the receptor from the inactive complex and consequently, relieves the masking effect of the ligand binding domain. The receptor dimerizes and subsequently binds to DNA response elements. Similar to other receptors, transcriptional activity of ER $\alpha$ requires the recruitment of steroid receptor coactivators. There are three members of the p160 class of steroid receptor coactivators: SRC-1 (ERAP160/NCoA-1), SRC-2 (TIF2/GRIP1/ 
NCoA-1), and SRC-3 (AIB1/RAC3/ACTR/TRAM1/pCIP) (Han et al., 2008). Once bound, the coactivators recruit the cointegrator $\mathrm{p} 300 / \mathrm{CBP}$ (CREB binding protein). The coregulator complex stimulates transcription by remodeling chromatin through its ability to acetylate histones and by its interaction with the basal transcription machinery (Lu et al., 1998).

Similar to other nuclear receptors (Wurtz et al., 1996;Renaud et al., 1996;Bourguet et al., 1995;Brzozowski et al., 1997; Wagner et al., 1995;Tanenbaum et al., 1998;Shiau et al., 1998), the ligand binding domain of ER $\alpha$ contains 11 alpha helices (H1, H3-H12) folded into a three layered antiparallel alpha helical sandwich. The central core layer contains the ligand binding pocket and is formed by three alpha-helices (H5/6, H9, and H10) sandwiched between two additional layers of helices composed of H1-4, H7, H8, and H11. The central core of the ligand binding pocket is flanked by H12. Based upon the crystal structure of apo- and holoRXR- $\alpha$ (Bourguet et al., 1995;Egea et al., 2000b), several major structural changes are thought to occur as a result of ligand binding; helix $\mathrm{H} 12$ is repositioned over the ligand binding pocket; helix $\mathrm{H} 11$ rotates around its helical axis and tilts away from the pocket; and the $\mathrm{N}$-terminal end of helix $\mathrm{H} 3$ rotates around its axis and bends towards helix $\mathrm{H} 4$ and the core of the pocket (Egea et al., 2000b;Bourguet et al., 1995) (figure 1). To account for these structural changes, it has been proposed (Wurtz et al., 1996; Egea et al., 2000a) that, once inside the pocket, the retinoid induces the rearrangement of helix $\mathrm{H} 3$ which, in turn, causes helix $\mathrm{H} 11$ to rotate and to form a continuous bent helix with helix H10. The repositioning of helix H11 pulls helix H12 under helix H4. The repositioning of helices $\mathrm{H} 3$ and $\mathrm{H} 12$ entraps the ligand in a manner similar to a mouse trap (Wagner et al., 1995) and results in the formation of a shallow hydrophobic groove that constitutes the AF-2 domain, the binding site for steroid receptor coactivators (Nolte $e t$ al., 1998). In the case of $\mathrm{ER} \alpha$, it has been suggested that, in addition to inducing a conformational change, estradiol functions inside the pocket as a scaffold for the structure of the ligand binding domain (Tanenbaum et al., 1998). The hydroxyl group on the A ring of the steroid hydrogen bonds with glu353 on helix H3, arg394 on helix H5, and a water molecule, while the hydroxyl group on the D ring hydrogen bonds with his524 on helix H11. In addition, the steroid backbone forms van der Waals interactions with hydrophobic amino acids on helices H3, H5, H7, and H1 1 and in the turn between the $\beta$ sheets (Brzozowski et al., 1997;Tanenbaum et al., 1998).

\section{MECHANISM OF CADMIUM ACTION}

Similar to estradiol, cadmium activates ER $\alpha$ through the ligand binding domain. When COS-1 cells are transiently cotransfected with GAL-ER, a chimeric receptor containing the DNA binding domain of the transcription factor GAL4 and the ligand binding domain of ER $\alpha$, a GAL4-responsive reporter gene, and treated with cadmium, there is an increase in reporter gene activity that is blocked by an antiestrogen suggesting that cadmium activates ER $\alpha$ through the ligand binding domain of the receptor. Scatchard analysis employing purified recombinant $\mathrm{ER} \alpha$ demonstrates a high affinity of cadmium for the receptor (Stoica et al., 2000a). Cadmium $\left({ }^{109} \mathrm{Cd}\right)$ binds with an equilibrium dissociation constant of approximately 4 to $5 \times 10^{-10} \mathrm{M}$. Cadmium also blocks the binding of estradiol to $\mathrm{ER} \alpha$ in a noncompetitive manner $(\mathrm{Ki}=2.96$ $\times 10^{-10} \mathrm{M}$ ) suggesting that the metal interacts with the ligand binding domain of the receptor. Mutational analysis identified cys381, cys447, glu523, his524, and asp538 as possible interaction sites of cadmium with the ligand binding domain of ER $\alpha$. Metals serve several different functions in proteins including participation in catalytic reactions and stabilization of protein structure. Through interactions with different amino acids, metals may promote local folding, as in the case of the zinc finger, or assembly of different regions of the protein into one domain (Rulisek et al., 1998). The amino acids identified as playing a role in the interaction of cadmium with ER $\alpha$ are located on helices $\mathrm{H} 4, \mathrm{H} 8$, and $\mathrm{H} 11$, and at the interface of the loop and helix H12 (figure 1B). Cysteines 381 and 447 are located on helices H4 and H8, respectively. Glutamic acid 523 and histidine 524 are located on helix H11 and are in close 
proximity to the ligand. Aspartic acid 538 is located at the loop-H12 interface and is also reasonably close to the ligand. Although the precise mechanism by which cadmium activates $\mathrm{ER} \alpha$ remains to be defined, it is possible that interaction of the metal with these amino acids induces structural changes that mimic the structural changes induced upon the binding of estradiol. For example, the interaction of cadmium with asp538 at the interface of loop and H12 may result in the movement of helix H12 over the ligand binding pocket; the interaction with glu523 on helix H11 may facilitate the formation of a continuous bent helix between helices $\mathrm{H} 10$ and $\mathrm{H} 11$; and the interaction with cys 381 on helix H4 may facilitate the formation of the coactivator binding site. This model remains to be tested.

\section{ANDROGENIC EFFECTS OF CADMIUM}

In the United States, it is currently estimated that the lifetime risk of developing prostate cancer is one in six for men. Every year, approximately 186,000 cases of prostate cancer are diagnosed and approximately 28,000 men die from the disease. The risk factors for prostate cancer include age, endocrine status, genetic susceptibility, occupation, ethnicity, race, ultraviolet radiation, diet, and environmental factors (Waalkes et al., 1994). Several studies suggest that exposure to cadmium is a risk factor for the disease, however, not all epidemiological studies support a role for the metal in the etiology of prostate cancer. The first studies to suggest a link between cadmium and prostate cancer showed an increased risk of the disease in occupationally exposed workers in a nickel-cadmium battery factory (Potts, 1965; Kipling and Waterhouse, 1967). A second study in smelter workers observed a significant increase in prostate cancer mortality but no evidence of an increased risk for the disease (Lemen et al., 1976). Several additional occupational studies demonstrated an association between cadmium exposure and an increase in prostate cancer risk and mortality (Dubrow et al., 1984;Blair and Fraumeni, 1979). However, more recent studies failed to show a link between occupational exposure to the metal and prostate cancer. While studies linking occupational exposure to cadmium with prostate cancer are inconsistent; studies linking environmental exposure to the metal with the disease showed an association. The latter studies found that prostate cancer was associated with dietary exposure to cadmium through drinking water and food (Elghany et al., 1990;Bako et al., 1980; West et al., 1991).

The growth and development of the prostate gland is under the control of androgenic sex steroids. The effects of androgens on the expression of genes involved in the growth as well as in the secretory function of the gland are mediated by the androgen receptor (AR). In addition to normal growth and function, androgens play a central role in the development of prostate cancer. A causal relationship between androgens and prostate cancer is supported by the sensitivity and response of many prostate cancers to hormonal therapy (Bosland, 2000; Waalkes and Rehm, 1994). Although the precise mechanism by which androgens affect prostate carcinogenesis is unknown, the hormones are strong promoters of the disease.

The LNCaP cells are an androgen dependent human prostate cancer cell line (Horoszewicz et al. 1980). In LNCaP cells, cadmium mimics the effects of androgens on cell growth (Martin et al., 2002;Webber, 1985) and gene expression (Martin et al., 2002). More importantly, environmentally relevant doses of cadmium mimic the effects of androgens in castrated rats and mice. Cadmium produces a dose-dependent increase in the wet weight of the prostate gland and the seminal vesicle complex that is blocked by an antiandrogen suggesting that the metal activates the androgen receptor in target tissue (Martin et al., 2002). In intact animals, addition of cadmium to the drinking water significantly increases the weight of the prostate and seminal vesicles and the increase in weight was not reversed upon castration (Visser et al., 1979). Taken together, these data suggest that cadmium is also a metalloandrogen and may explain, in part, the risk of prostate cancer associated with exposure to the metal. 
The androgen receptor is also a member of the superfamily of genes that encode for the steroid receptors (figure 1). Similar to other members of the superfamily, the ligand binding domain of AR is folded into a three layered antiparrallel alpha helical structure. Unlike the ligand binding domain of ER $\alpha$ that has 11 alpha helices, the ligand binding domain of the androgen receptor is thought to contain only ten alpha helices (Matias et al., 2000;Sack et al., 2001). The AR is missing helix H2 and helices H10 and H11 are contiguous (Matias et al., 2000;Sack et al., 2001; Williams et al., 1998). Similar to ER $\alpha$, cadmium activates a chimera containing the ligand binding domain of the AR in transfection assays (Martin et al., 2002). In addition, the metal binds with high affinity to the ligand binding domain (Martin et al., 2002;Donovan et al., 1979 ) and blocks the binding of androgen to the receptor. Scatchard analysis demonstrated that cadmium binds to AR with an equilibrium dissociation constant of $1.19 \times 10^{-10} \mathrm{M}$. The similarities between the ligand binding domains of AR and ER $\alpha$ and the ability of the metal to bind to and activate AR through the ligand binding domain suggest that cadmium may activate AR and ER $\alpha$ by a similar mechanism. In support of a similar mechanism, sequence alignment demonstrates that some of the amino acids identified as important in the interaction of cadmium with $E R \alpha$ are conserved in the ligand binding domain of the androgen receptor. However, further studies are required to define the precise mechanism by which cadmium activates the androgen receptor.

\section{SUMMARY}

Although additional population and laboratory studies are required to establish a link between environmental exposure to cadmium in the causal pathway of hormone related diseases, in vitro and in vivo studies conducted to date suggest that cadmium can function biologically as an estrogen and an androgen. The ability to bind to and activate steroid receptors is the likely cause of the hormone like effects of the metal. Although it has been demonstrated that cadmium binds with high affinity to the ligand binding domain of ER $\alpha$ and AR and, presumably, induces a conformational change that mimics the effects of the cognate hormone, additional laboratory studies are required to define the mechanism by which cadmium activates steroid receptors. In addition to the laboratory studies, the impact of environmental exposure to cadmium and other metalloestrogens on the incidence of breast and prostate cancer needs to be more thoroughly investigated within diverse populations. If as suggested that exposure to metalloestrogens could explain as much as $30 \%$ of these cancers, then increased environmental exposures to metals over the last half century may explain a large portion of the increased rates of these cancers in developed countries.

\section{References}

Akesson A, Julin B, Wolk A. Long-term dietary cadmium intake and postmenopausal endometrial cancer incidence: a population-based prospective cohort study. Cancer Res 2008;68:6435-6441. [PubMed: 18676869]

Althuis MD, Dozier JM, Anderson WF, Devesa SS, Brinton LA. Global trends in breast cancer incidence and mortality 1973-1997. Int J Epidemiol 2005;34:405-412. [PubMed: 15737977]

Bako G, Smith ESO, Hanson J, Dewar R. The geographical distribution of high cadmium concentrations in the environment and prostate cancer in Alberta. Can J Public Health 1980;73:92-94. [PubMed: 7104934]

Blair A, Fraumeni JF. Geographic patterns of prostate cancer in the United States. J Natl Cancer Inst 1979;61:1379-1384. [PubMed: 281545]

Boice JD Jr. Miller RW. Childhood and adult cancer after intrauterine exposure to ionizing radiation. Teratology 1999;59:227-233. [PubMed: 10331524]

Bosland MC. The role of steroid hormones in prostate carcinogenesis. J Natl Cancer Inst Monographs 2000;27:39-66. [PubMed: 10963619] 
Bourguet W, Ruff M, Chambon P, Gronemeyer H, Moras D. Crystal structure of the ligand-binding domain of the human nuclear receptor RXR-alpha. Nature 1995;375:377-382. [PubMed: 7760929]

Brama M, Gnessi L, Basciani S, Cerulli N, Politi L, Spera G, Mariani S, Cherubini S, d'Abusco AS, Scandurra R, Migliaccio S. Cadmium induces mitogenic signaling in breast cancer cell by an ERalphadependent mechanism. Mol Cell Endocrinol 2007;264:102-108. [PubMed: 17125913]

Brooks SC, Locke ER, Soule HD. Estrogen receptor in a human cell line (MCF-7) from breast carcinoma. J Biol Chem 1973;248:6251-6253. [PubMed: 4353636]

Brzozowski AM, Pike ACW, Dauter Z, Hubbard RE, Bonn T, Engstrom O, Ohman L, Greene GL, Gustafsson J, Carlquist M. Molecular basis of agonism and antagonism in the estrogen receptor. Nature 1997;389:753-758. [PubMed: 9338790]

Cantor KP, Stewart PA, Brinton LA, Dosemeci M. Occupational exposures and female breast cancer mortality in the United States. J Occup Med 1994;37:336-348.

Choe SY, Kim SJ, Kim HG, Lee JH, Choi Y, Lee H, Kim Y. Evaluation of estrogenicity of major heavy metals. Sci Total Environ 2003;312:15-21. [PubMed: 12873394]

Colborn T, von Saal FS, Soto AM. Developmental effects of endocrine-disrupting chemicals in wildlife and humans. Environ Health Perspect 1993;101:378-384. [PubMed: 8080506]

Cowley SM, Hoare S, Mosselman S, Parker MG. Estrogen receptors alpha and beta form heterodimers on DNA. J Biol Chem 1997;272:19858-19862. [PubMed: 9242648]

Darbre PD. Aluminium, antiperspirants and breast cancer. J Inorg Biochem 2005;99:1912-1919. [PubMed: 16045991]

Donovan MP, Schein LG, Thomas JA. Inhibition of AR interaction in mouse prostate gland cytosol by divalent metal ions. Mol Pharmacol 1979;17:156-162. [PubMed: 7393202]

Dorgan JF, Baer DJ, Albert PS, Judd JT, Brown ED, Corle DK, Campbell WS, Hartman TJ, Tejpar AA, Clevidence BA, Giffen CA, Chandler DW, Stanczyk FZ, Taylor PR. Serum hormones and the alcohol-breast cancer association in postmenopausal women. J Natl Cancer Inst 2001;93:710-715. [PubMed: 11333294]

Dubrow R, Wegman DH. Cancer and occupation in Massachusetts: A death certificate study. Am J Ind Med 1984;6:207-230. [PubMed: 6475966]

Egea PF, Klaholz BP, Moras D. Ligand-protein interactions in nuclear receptors of hormones. FEBS Lett 2000a;476:62-67. [PubMed: 10878252]

Egea PF, Mitschler A, Rochel N, Ruff M, Chambon P, Moras D. Crystal structure of the human RXRalpha ligand-binding domain bound to its natural ligand: 9-cis retinoic acid. EMBO J 2000b;19:2592-2601. [PubMed: 10835357]

Elghany NA, Schumacher MC, Slattery ML, West DW, Lee JS. Occupation, cadmium exposure, and prostate cancer. Epidemiology 1990;1:107-115. [PubMed: 2073496]

Feigelson HS, Jonas CR, Teras LR, Thun MJ, Calle EE. Weight gain, body mass index, hormone replacement therapy, and postmenopausal breast cancer in a large prospective study. Cancer Epidemiol Biomarkers Prev 2004;13:220-224. [PubMed: 14973094]

Feuer EJ, Wun LM, Boring CC, Flanders WD, Timmel MJ, Tong T. The lifetime risk of developing breast cancer. J Natl Cancer Inst 1993;85:892-897. [PubMed: 8492317]

Garcia-Morales P, Saceda M, Kenney N, Kim N, Salomon DS, Gottardis MM, Solomon HB, Sholler PF, Jordan VC, Martin MB. Effect of cadmium on estrogen receptor levels and estrogen-induced responses in human breast cancer cells. J Biol Chem 1994;269:16896-16901. [PubMed: 8207012]

Han SJ, Lonard DM, O’Malley BW. Multi-modulation of nuclear receptor coactivators through posttranslational modifications. Trends Endocrinol Metab 2009;20:8-15. [PubMed: 19019695]

Hankinson SE, Willett WC, Manson JE, Colditz GA, Hunter DJ, Spiegelman D, Barbieri RL, Speizer FE. Plasma sex steroid hormone levels and risk of breast cancer in postmenopausal women. J Natl Cancer Inst 1998;90:1292-1299. [PubMed: 9731736]

Henderson BE, Ross RK, Judd HL, Krailo MD, Pike MC. Do regular ovulatory cycles increase breast cancer risk? Cancer 1985;56:1206. [PubMed: 4016708]

Horoszewicz JS, Leong SS, Chu TM, Wajsman ZL, Friedman M, Papsidero L, Kim U, Chai LS, Kakati S, Arya SK, Sandberg AA. The LNCaP cell line - a new model for studies on human prostate carcinoma. Prog Lin Biol Res 1980;37:115-132. 
Hoover R, Gray LA Sr. Cole P, MacMahon B. Menopausal estrogens and breast cancer. N Engl J Med 1976;295:401-405. [PubMed: 180409]

Johnson MD, Kenney N, Stoica A, Hilakivi-Clarke L, Singh B, Chepko G, Clarke R, Sholler PF, Lirio AA, Foss C, Reiter R, Trock B, Palk S, Martin MB. Cadmium mimics the in vivo effects of estrogen in the uterus and mammary gland. Nature Med 2003;9:1081-1084. [PubMed: 12858169]

Kampert JB, Whittemore AS, Paffenbarger RS Jr. Combined effect of child-bearing, menstrual events, and body size on age-specific breast cancer risk. Am J Epidemiol 1988;128:962-979. [PubMed: 3189296]

Kipling MD, Waterhouse JAH. Cadmium and prostatic carcinoma. Lancet 1967;28:199-204.

Krust A, Green S, Argos P, Kumar V, Walter P, Bornert JM, Chambon P. The chicken oestrogen receptor sequence: Homology with v-erbA and the human oestrogen and glucocorticoid receptors. EMBO J 1986;5:891-897. [PubMed: 3755102]

Kumar V, Green S, Stack G, Berry M, Jin JR, Chambon P. Functional domains of the human estrogen receptor. Cell 1987;51:941-951. [PubMed: 3690665]

Land CE. Studies of cancer and radiation dose among atomic bomb survivors. The example of breast cancer. JAMA 1995;274:402-407. [PubMed: 7616636]

Lemen RA, Lee JS, Wagoner JK, Blefer HP. Cancer mortality among cadmium production workers. Ann NY Acad Sci 1976;271:273-279. [PubMed: 1069514]

Lippman, ME. Endocrine responsive cancers of man. In: Williams, RH., editor. Textbook of Endocrinology. W.B.Saunders; Philadelphia: 1985. p. 1309-1326.

Liu Z, Yu X, Shaikh ZA. Rapid activation of ERK1/2 and AKT in human breast cancer cells by cadmium. Toxicol Appl Pharmacol 2008;228:286-294. [PubMed: 18275979]

$\mathrm{Lu}$ J, Danielsen M. Differential regulation of androgen and glucocorticoid receptors by retinoblastoma protein. J Biol Chem 1998;273:31528-31533. [PubMed: 9813067]

MacMahon B, Cole P, Brown J. Etiology of human breast cancer: a review. J Natl Cancer Inst 1973;50:21. [PubMed: 4571238]

Madigan MP, Ziegler RG, Benichou J, Byrne C, Hoover RN. Proportion of breast cancer cases in the United States explained by well-established risk factors. J Natl Cancer Inst 1995;87:1681-1685. [PubMed: 7473816]

Martin MB, Reiter R, Pham T, Avellanet YR, Camara J, Lahm M, Pentecost E, Pratap K, Gilmore B, Divekar S, Dagata RS, Bull J, Stoica A. Estrogen like activity of metals in MCF-7 breast cancer cells. Endocrinol 2003;144:2425-2436.

Martin MB, Voeller HJ, Gelmann EP, Lu J, Stoica EG, Hebert EJ, Reter R, Singh B, Danielsen M, Pentecost E, Stocia A. Role of cadmium in the regulation of AR gene expression and activity. Endocrinol 2002;143:263-275.

Martinez-Campa C, Alonso-Gonzalez C, Mediavilla MD, Cos S, Gonzalez A, Ramos S, Sanchez-Barcelo EJ. Melatonin inhibits both ER alpha activation and breast cancer cell proliferation induced by a metalloestrogen, cadmium. J Pineal Res 2006;40:291-296. [PubMed: 16635015]

Matias PM, Donner P, Coelho R, Thomaz M, Peixoto C, Macedo S, Otto N, Joschko S, Scholz P, Wegg A, Basler S, Schafer M, Egner U, Carrondo MA. Structural evidence for ligand specificity in the binding domain of the human androgen receptor. Implications for pathogenic gene mutations. J Biol Chem 2000;275:26164-26171. [PubMed: 10840043]

McElroy JA, Shafer MM, Trentham-Dietz A, Hampton JM, Newcomb PA. Cadmium exposure and breast cancer risk. J Natl Cancer Inst 2006;98:869-873. [PubMed: 16788160]

Miki Y, Swensen J, Shattuck-Eidens D, Futreal PA, Harshman K, Tavtigian S, Liu Q, Cochran C, Bennett LM, Ding W, et al. A strong candidate for the breast and ovarian cancer susceptibility gene BRCA1. Science 1994;266:66-71. [PubMed: 7545954]

Nolte RT, Wisely GB, Westin S, Cobb JE, Lambert MH, Kurokawa R, Rosenfeld MG, Willson TM, Glass CK, Milburn MV. Ligand binding and co-activator assembly of the peroxisome proliferatoractivated receptor-gamma. Nature 1998;395:137-143. [PubMed: 9744270]

Peeters PH, Keinan-Boker L, van der Schouw YT, Grobbee DE. Phytoestrogens and breast cancer risk. Review of the epidemiological evidence. Breast Cancer Res Treat 2003;77:171-183. [PubMed: 12602916] 
Pettersson K, Delaunay F, Gustafsson JA. Estrogen receptor beta acts as a dominant regulator of estrogen signaling. Oncogene 2000;19:4970-4978. [PubMed: 11042684]

Pettersson K, Gustafsson JA. Role of estrogen receptor beta in estrogen action. Annu Rev Physiol 2001;63:165-192. [PubMed: 11181953]

Pike MC, Henderson BE, Casagrande JT, Rosario I, Gray GE. Oral contraceptive use and early abortion as risk factors for breast cancer in young women. Br J Cancer 1981;43:72. [PubMed: 7459241]

Potts CL. Cadmium proteinuria-The health of battery workers exposed to cadmium oxide dust. Ann Occup Hyg 1965;8:55-61. [PubMed: 14287870]

Raymond-Whish S, Mayer LP, O’Neal T, Martinez A, Sellers MA, Christian PJ, Marion SL, Begay C, Propper CR, Hoyer PB, Dyer CA. Drinking water with uranium below the U.S. EPA water standard causes estrogen receptor-dependent responses in female mice. Environ Health Perspect 2007;115:1711-1716. [PubMed: 18087588]

Renaud JP, Rochel N, Ruff M, Vivat V, Chambon P, Gronemeyer H, Moras D. Crystal structure of the RAR-gamma ligand-binding domain bound to all-trans retinoic acid. Nature 1996;378:681-689. [PubMed: 7501014]

Richie RC, Swanson JO. Breast cancer: a review of the literature. J Insur Med 2003;35:85-101. [PubMed: 14733031]

Rulisek L, Vondrasek J. Coordination geometries of selected transition metal ions $(\mathrm{Co} 2+, \mathrm{Ni} 2+, \mathrm{Cu} 2+$, $\mathrm{Zn2+,} \mathrm{Cd2+,} \mathrm{and} \mathrm{Hg2+)} \mathrm{in} \mathrm{metalloproteins.} \mathrm{J} \mathrm{Inorganic} \mathrm{Biochem} \mathrm{1998;71:115-127.}$

Sack JS, Kish KF, Wang C, Attar RM, Kiefer SE, An Y, Wu GY, Scheffler JE, Salvati ME, Krystek SR Jr. Weinmann R, Einspahr HM. Crystallographic structures of the ligand-binding domains of the androgen receptor and its T877A mutant complexed with the natural agonist dihydrotestosterone. Proc Natl Acad Sci USA 2001;98:4904-4909. [PubMed: 11320241]

Safe S. Endocrine disruptors and human health: is there a problem. Toxicology 2004;205:3-10. [PubMed: 15458784]

Safe SH. Environmental and dietary estrogens and human health: is there a problem? Environ Health Perspect 1995;103:346-351. [PubMed: 7607134]

Shiau AK, Barstad D, Loria PM, Cheng L, Kushner PJ, Agard DA, Greene GL. The structural basis of estrogen receptor/coactivator recognition and the antagonism of this interaction by tamoxifen. Cell 1998;95:927-937. [PubMed: 9875847]

Stoica A, Katzenellenbogen BS, Martin MB. Activation of estrogen receptor-alpha by the heavy metal cadmium. Mol Endocrinol 2000a;14:545-553. [PubMed: 10770491]

Stoica A, Pentecost E, Martin MB. Effect of arsenite on estrogen receptor-a expression and activity in MCF-7 breast cancer cells. Endocrinol 2000b;141:3595-3602.

Stoica A, Pentecost E, Martin MB. Effects of selenite on estrogen receptor-a expression and activity in MCF-7 breast cancer cells. J Cell Biochem 2000c;79:282-292. [PubMed: 10967555]

Tanenbaum DM, Wang Y, Williams SP, Sigler PB. Crystallographic comparison of the estrogen and progesterone receptor's ligand binding domain. Proc Natl Acad Sci USA 1998;95:5998-6003. [PubMed: 9600906]

Tokunaga M, Land CE, Yamamoto T, Asano M, Tokuoka S, Ezaki H, Nishimori I. Incidence of female breast cancer among atomic bomb survivors, Hiroshima and Nagasaki, 1950-1980. Radiat Res 1987;112:243-272. [PubMed: 3685255]

Toniolo PG, Levitz M, Zeleniuch-Jacquotte A, Banerjee S, Koenig KL, Shore RE, Strax P, Pasternack BS. A prospective study of endogenous estrogens and breast cancer in postmenopausal women. J Natl Cancer Inst 1995;87:190-197. [PubMed: 7707406]

Ursin, G.; Bernstein, L.; Pike, MC. Breast cancer. In: Doll, R.; Fraumeni, JF.; Muir, CS., editors. Cancer Surveys. Cold Spring Harbor Laboratory Press; Plainview, NY: 1994. p. 241-264.

Veselik DJ, Divekar S, Dakshanamurthy S, Storchan GB, Turner JM, Graham KL, Huang L, Stoica A, Martin MB. Activation of estrogen receptor-alpha by the anion nitrite. Cancer Res 2008;68:39503958. [PubMed: 18483281]

Visser AJ, Deklerk JN. The effect of dietary cadmium on prostate growth. Trans Am Assoc GenitoUrinary Surg 1979;70:66-68.

Waalkes MP, Rehm S. Cadmium and prostate cancer. J Toxicol Environ Health 1994;43:251-269. [PubMed: 7966437] 
Wagner RL, Apriletti JW, McGrath ME, West BL, Baxter JD, Fletterick RJ. A structural role for hormone in the thyroid hormone receptor. Nature 1995;378:690-697. [PubMed: 7501015]

Webber MM. Selenium prevents the growth stimulatory effects of cadmium on human prostate epithelium. Biochem Biophy Res Comm 1985;127:871-877.

West DW, Slattery ML, Robinson LM, French TK, Mahoney AW. Adult dietery intake and prostate cancer risk in Utah. A case-control study with special emphasis on aggressive tumors. Cancer Causes Control 1991;2:85-94. [PubMed: 1873441]

Williams SP, Sigler PB. Atomic structure of progesterone complexed with its receptor. Nature 1998;393:392-396. [PubMed: 9620806]

Wilson VS, Bobseine K, Gray LE Jr. Development and characterization of a cell line that stably expresses an estrogen-responsive luciferase reporter for the detection of estrogen receptor agonist and antagonists. Toxicol Sci 2004;81:69-77. [PubMed: 15166400]

Wurtz JM, Bourguet W, Renaud JP, Vivat V, Chambon P, Moras D, Gronemeyer H. A canonical structure for the ligand-binding domain of nuclear receptors. Nat Struct Biol 1996;3:87-94. [PubMed: 8548460]

Yong LC, Brown CC, Schatzkin A, Schairer C. Prospective study of relative weight and risk of breast cancer: the Breast Cancer Detection Demonstration Project follow-up study, 1979 to 1987-1989. Am J Epidemiol 1996;143:985-995. [PubMed: 8629617] 


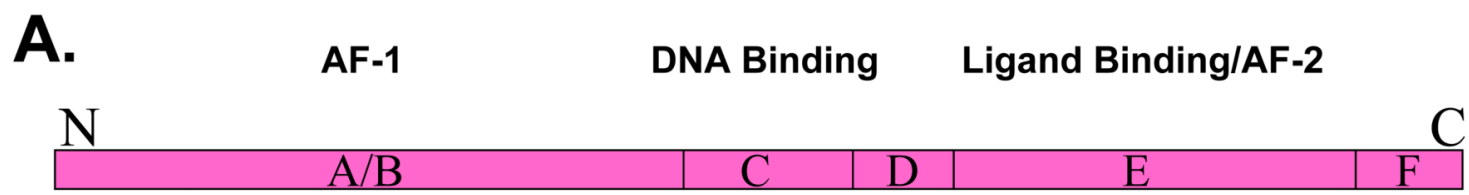

AR

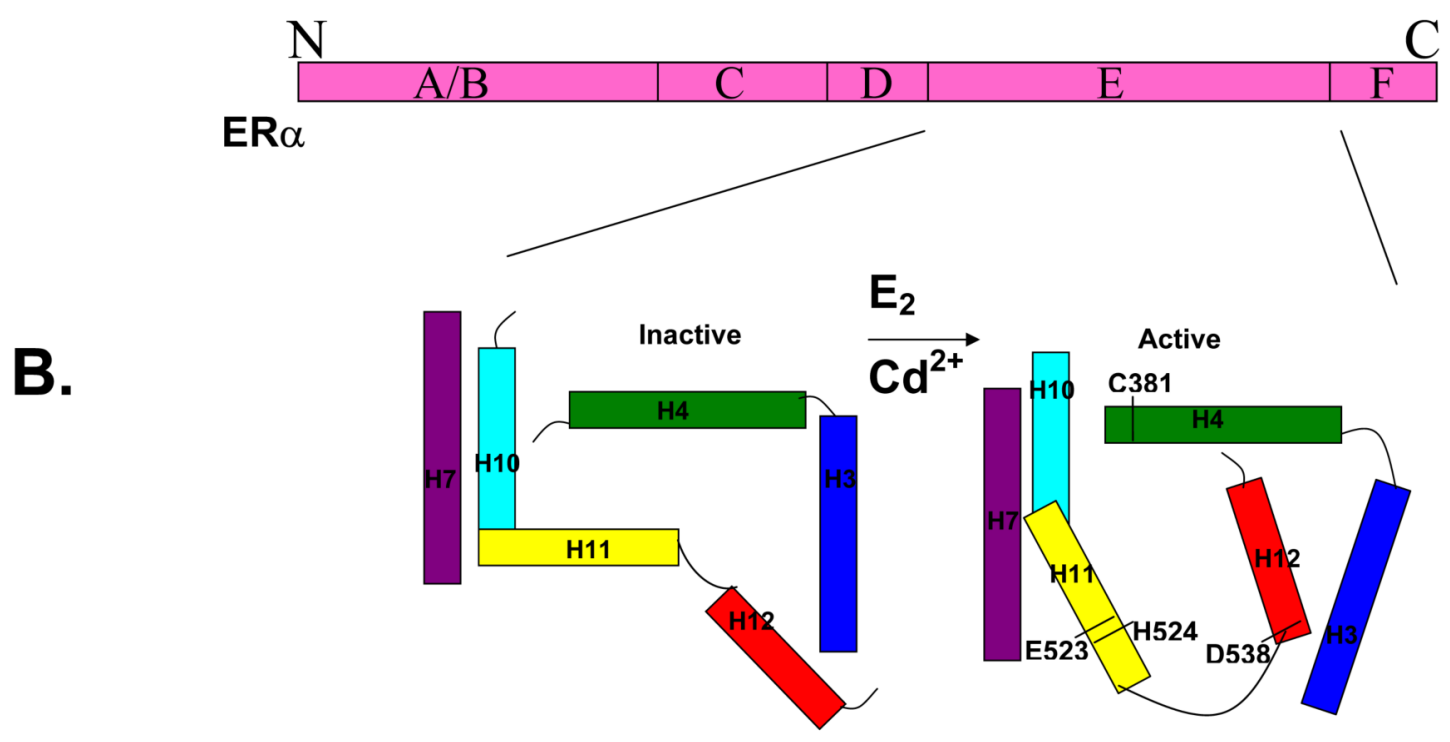

Figure 1.

Proposed model for cadmium induced activation of ER $\alpha$.

A. Domain structure of the androgen receptor and estrogen receptor-alpha.

Estrogen receptor-alpha $(\mathrm{ER} \alpha)$ and androgen receptor (AR) are divided into domains, termed A through $\mathrm{F}$. The $\mathrm{N}$-terminus of the receptor contains the $\mathrm{A} / \mathrm{B}$ region which is a variable region that modulates transcription through a domain referred to as activation function-1 (AF-1). The DNA binding domain, region $\mathrm{C}$, is a short well conserved cysteine rich region that contains two zinc fingers. In addition to DNA binding, region $\mathrm{C}$ plays a role in transactivation and dimerization. The $\mathrm{C}$-terminus of the receptor contains regions $\mathrm{D}, \mathrm{E}$, and $\mathrm{F}$. Region $\mathrm{E}$ is the ligand binding domain that contains the hormone inducible dimerization and activation function-2 (AF-2) domains. The ligand binding domain of $\mathrm{ER} \alpha$ contains 11 alpha helices (H1, H3-H12) folded into a three layered antiparallel alpha helical sandwich surrounding the ligand binding pocket. B. Schematic model of helices H3, H4, H7 and H10-H12 of the ligand binding domain of $\mathrm{ER} \alpha$.

In the absence of estradiol $\left(\mathrm{E}_{2}\right)$, the ligand binding domain is in an inactive state. It has been proposed that, in the inactive state, the ligand binding domain of ER $\alpha$ is an open state with helix H10 and helix H11 in a perpendicular conformation and helix H12 positioned away from the ligand bind pocket. Upon estradiol binding, the dimerization domain of the receptor is formed by the rotation of helix $\mathrm{H} 11$ and the formation of a continuous bent helix with helix $\mathrm{H} 10$. The coactivator binding site is formed when helix H12 is repositioned under helix H4 closing the ligand binding pocket. It is proposed that, upon cadmium binding to amino acids C381, E523, H524 and D538 in the ligand binding domain, ER $\alpha$ undergoes similar structural changes to form the active state of the receptor. 